\title{
Association of Polymorphisms in PPARPGC1A, ACE, and DRD2 Genes with Gestational Diabetes Mellitus
}

\author{
Agamurad A. Orazmuradov, PhD, $\mathrm{ScD}^{1}$; Irina V. Bekbaeva ${ }^{1^{*}}$; Gayane A. Arakelyan ${ }^{1}$; \\ Marianna Z. Abitova ${ }^{1}$; Khalid Haddad ${ }^{1}$; Alexander M. Lopatin ${ }^{1}$; Sergey I. Kyrtikov ${ }^{1}$; \\ Gulnoza K. Eldashova ${ }^{1}$; Ekaterina V. Mukovnikova ${ }^{1}$; Aleksey A. Lukaev, PhD ${ }^{2}$ \\ 'Peoples' Friendship University of Russia (RUDN University), Moscow, Russia \\ ${ }^{2}$ Mytishchi City Clinical Hospital Mytishchi, Moscow Region, Russia
}

\begin{abstract}
The aim of our research was to study the distribution of polymorphic variants of the DRD2/ANKK1 TaqIA (rs1800497 SNP), PPARGC1A rs8192678 SNP, and ACE I/D in gestational diabetes mellitus (GDM).

Methods and Results: The study included 383 pregnant women (gestational age of 37.0-41.0 weeks) with GDM and 68 pregnant women without disturbed carbohydrate metabolism. This was a prospective case-control study. All patients were divided into 3 groups. Group 1 included 211 pregnant women with GDM who received diet therapy only; Group 2 included 172 pregnant women with GDM who received insulin therapy; Group 3 included 68 pregnant women without metabolic disorders. For the DRD2/ANKK1 TaqIA (rs1800497 SNP) (A1/A2; T/C), we found that the TT homozygous genotype and T allele prevailed in Groups with GDM compared with Group without metabolic disorders.

Conclusion: A study of the DRD2/ANKK1 TaqIA (rs1800497 SNP), PPARGC1A rs8192678 SNP, and ACE I/D revealed statistically significant increased risks for GDM in carriers of the TT genotype and T allele of the DRD2/ANKK1 TaqIA (rs1800497 SNP).(International Journal of Biomedicine. 2021;11(1):42-45.)

Key Words: gestational diabetes mellitus $\bullet$ dopamine D2 receptor $\bullet$ PPARPGC-1A • angiotensin-converting enzyme

For citation: Orazmuradov AA, Bekbaeva IV, Arakelyan GA, Abitova MZ, Haddad Kh, Lopatin AM, Kyrtikov SI, Eldashova GK, Mukovnikova EV, Lukaev AA. Association of Polymorphisms in PPARPGC-1A, ACE, and DRD2 Genes with Gestational Diabetes Mellitus. International Journal of Biomedicine. 2021;11(1):42-45. doi:10.21103/Article11(1)_OA8
\end{abstract}

\section{Abbreviations}

DRD2, dopamine D2 receptor; GDM, gestational diabetes mellitus; PPARPGC1A, peroxisome proliferator-activated receptor gamma coactivator 1-alpha; ACE, angiotensin-converting enzyme; T2DM, type 2 diabetes mellitus.

\section{Introduction}

Despite the well-known role of pregestational obesity in the pathogenesis of gestational diabetes mellitus (GDM), the role of polymorphism of genes responsible for the regulation of carbohydrate and fat metabolism in GDM

"Corresponding author: Irina V. Bekbaeva, Peoples' Friendship University of Russia (RUDN University), Moscow, Russia.E-mail: iridescentgirl@yandex.ru has been insufficiently studied. ${ }^{(1-3)}$ The available data are quite contradictory. In particular, the significance of the polymorphisms in the DRD2 gene, PPARGC1A gene, and $A C E$ gene has been studied in most detail in relation to T2DM. ${ }^{(1,4,5)}$ It should be noted that data on the role of genetic mechanisms in the formation of the complicated course of GDM are extremely few in number. However, current studies report a possible close relationship between genes responsible for the development of T2DM and of GDM. ${ }^{(6)}$

Several studies show that the Alu Insertion/Deletion ( $A C E \mathrm{I} / \mathrm{D})$ polymorphism present on intron 16 of the $A C E$ gene 
is associated with T2DM and diabetes-related complications..$^{(6,7)}$ Significant associations of ACE SNP's, C1237T, and G2350A with GDM were observed. Haplotype analysis revealed the remarkably significant evidence of association with SNP combination ACE A240T, C1237T, G2350A, and I/D with GDM patients $(P=0.024){ }^{(6)}$ However, the information about the role of this gene in the development of GDM in the world scientific literature is ambiguous. There are studies that disprove the association of the $A C E$ gene polymorphisms with GDM. ${ }^{(8)}$

There is also little information about the role of polymorphisms of other genes responsible for carbohydrate metabolism disorders, such as DRD2, PPARGC1A (PGC-1 alpha), in the pathogenesis of GDM.

SNP rs8192678 (in exon 8, G1444A/Gly482Ser) is the most important polymorphism of the PPARGC1A gene. ${ }^{(9,10)}$ It may be a functional point mutation associated with altered gene expression. Altered gene expression might contribute to insulin resistance by impaired metabolic pathways (e.g. PPAR-mediated adipocyte differentiation, lipid oxidation, gluconeogenesis in the liver or glucose transport in the muscles). ${ }^{(10-13)}$ The negative effect of the minor 482Ser allele has been described on metabolic and cardiovascular traits, such as insulin sensitivity and secretion, measures of obesity, lipid and glucose concentrations, adiponectin level, aerobic fitness. ${ }^{(9,10,13)}$

A widely studied SNP, the so-called DRD2/ANKK1 Taq1A polymorphism (rs1800497, C32806T, Glu713Lys) is located $\sim 10 \mathrm{~kb}$ downstream from the DRD2 gene in the ankyrin repeat and kinase domain containing 1 (ANKK1) gene. ${ }^{(14)}$ However, individuals who carry the A1 (T) allele have reduced brain D2 receptor density, ${ }^{(15)}$ which has been demonstrated to increase the risk for overeating and obesity. ${ }^{(16,17)}$

The aim of our research was to study the distribution of polymorphic variants of the DRD2/ANKK1 TaqIA (rs 1800497 SNP), PPARGC1A rs8192678 SNP, and $A C E$ I/D in GDM.

\section{Materials and Methods}

The study included 383 pregnant women with GDM and 68 pregnant women without disturbed carbohydrate metabolism, who gave birth between the second quarter of 2019 and the third quarter of 2020 (gestational age of 37.0-41.0 weeks). This was a prospective case-control study. Diagnosis of GDM was based on the criteria of the American College of Obstetricians and Gynecologists. ${ }^{(18)}$ All patients were divided into 3 groups. Group 1 included 211 pregnant women with GDM who received diet therapy only; Group 2 included 172 pregnant women with GDM who received insulin therapy; Group 3 included 68 pregnant women without metabolic disorders.

The surveyed patients were questioned about: 1) family history of disorders of carbohydrate metabolism and obesity; 2) chronic somatic and gynecological diseases; 3) reproductive history; and 4) complications of current pregnancy, the timing of GDM detection.

After DNA extraction, the samples were subjected to a PCR-RFLP reaction to analyze the DRD2/ANKK1 TaqIA (rs1800497 SNP), the PPARGC1A rs8192678 SNP, and the $A C E \mathrm{I} / \mathrm{D}$ polymorphism.
Genomic DNA was isolated the peripheral blood leukocytes using standard extraction technique using kits from QIAmpDNABloodMiniKit» («Qiagen», Germany). Genotyping of the $A C E$ I/D polymorphism was performed using a PCR method as previously described. ${ }^{(19)}$ The PPARGC1A rs8192678 SNP was genotyped by PCRRFLP analysis. ${ }^{(20)}$ Genotyping of the DRD2/ANKK1 TaqIA (rs1800497) polymorphism was performed by PCR-RFLP analysis. $^{(21)}$

Statistical analysis was performed using the Statistica v.10 software package (StatSoft Inc, USA). The frequency distribution of genotypes for the studied polymorphic loci was checked for compliance with the Hardy-Weinberg equilibrium (HWE). ${ }^{(22)}$ To check the statistical significance of the differences between the groups, we used Pearson $\chi 2$ test. Odds ratios (ORs) and 95\% confidence intervals (CIs) were calculated. A value of $P<0.05$ was considered statistically significant.

\section{Results and Discussion}

The genotype frequencies of all studied polymorphisms were in compliance with HWE $(P>0.05)$ (Tables 1-3).

An analysis of the frequency distribution of genotypes and alleles of the PPARGC1A rs8192678 SNP showed no differences between groups (Table 1).

Table 1.

Distribution of alleles and genotypes of the PPARGC1A rs8192678 SNP in the studied groups

\begin{tabular}{|c|c|c|c|c|}
\hline $\begin{array}{l}\text { Genotype/ } \\
\text { allele }\end{array}$ & $\begin{array}{l}\text { Group } 1 \\
(n=133)\end{array}$ & $\begin{array}{l}\text { Group } 2 \\
(n=110)\end{array}$ & $\begin{array}{c}\text { Group } 3 \\
(n=50)\end{array}$ & Statistics \\
\hline Ser/Ser & $15(11.38 \%)$ & $18(16.4 \%)$ & $4(8 \%)$ & \multirow{3}{*}{$\begin{array}{c}\chi^{2}=3.261 \\
\mathrm{df}=4 ; P=0.5151\end{array}$} \\
\hline Gly/Ser & $72(54.1 \%)$ & $61(55.4 \%)$ & $30(60 \%)$ & \\
\hline Gly/Gly & $46(34.6 \%)$ & $31(28.2 \%)$ & $16(32 \%)$ & \\
\hline Ser & $102(38.3 \%)$ & $97(44.1 \%)$ & $38(38 \%)$ & \multirow{2}{*}{$\begin{array}{c}\chi^{2}=1.959 \\
\mathrm{df}=2 ; P=0.3774\end{array}$} \\
\hline Gly & $164(61.7 \%)$ & $123(55.9 \%)$ & $62(62 \%)$ & \\
\hline $\begin{array}{l}\text { Compliance } \\
\text { with HWE }\end{array}$ & $\chi^{2}=2.79$ & $\chi^{2}=1.71$ & $\chi^{2}=3.74$ & \\
\hline
\end{tabular}

For the $D R D 2 / A N K K 1$ TaqIA (rs1800497 SNP) (A1/A2; $\mathrm{T} / \mathrm{C}$ ), we found that the TT homozygous genotype and T allele prevailed in Groups 1 and 2 compared with Group 3 (Table 2 ). The carriage of the $\mathrm{T}$ allele of the DRD2/ANKK1 TaqIA (rs1800497 SNP) was associated with increased risk of GDM (Group 1: OR=2.286; 95\% CI: 1.320-3.957; $P<0.0 .1$ Group 2: $\mathrm{OR}=2.436 ; 95 \% \mathrm{CI}: 1.384-4.289 ; P<0.01)$

An analysis of the frequency distribution of genotypes and alleles of the $A C E \mathrm{I} / \mathrm{D}$ polymorphism showed no differences between groups (Table 3 ).

The results obtained regarding the $A C E$ I/D polymorphism were not similar to a previous study conducted by Parul Aggarwal et al. ${ }^{(6)}$ and Mani Mirfeizi et al., ${ }^{(8)}$ in which the researchers found the prevalence of the DD genotype in women with GDM compared to healthy women. 
Table 2 .

Distribution of alleles and genotypes of the DRD2/ANKK1 TaqIA (rs1800497 SNP) in the studied groups

\begin{tabular}{|c|c|c|c|c|}
\hline $\begin{array}{l}\text { Genotype/ } \\
\text { allele }\end{array}$ & $\begin{array}{c}\text { Group } 1 \\
(n=72)\end{array}$ & $\begin{array}{c}\text { Group } 2 \\
(\mathrm{n}=61)\end{array}$ & $\begin{array}{c}\text { Croup } 3 \\
(\mathrm{n}=51)\end{array}$ & Statistics \\
\hline $\mathrm{C} / \mathrm{T}$ & $37(51.4 \%)$ & $27(44.3 \%)$ & $23(60.5 \%)$ & \multirow{3}{*}{$\begin{array}{c}\chi^{2}=12.47 \\
\mathrm{df}=4 ; P=0.0142\end{array}$} \\
\hline $\mathrm{C} / \mathrm{C}$ & $21(29.2 \%)$ & $19(31.1 \%)$ & $26(34.2 \%)$ & \\
\hline $\mathrm{T} / \mathrm{T}$ & $14(19.4 \%)$ & $15(24.6 \%)$ & $2(5.3 \%)$ & \\
\hline $\mathrm{C}$ & $79(54.9 \%)$ & $65(53.3 \%)$ & $75(73.5 \%)$ & \multirow{2}{*}{$\begin{array}{c}\chi^{2}=11.578 \\
\mathrm{df}=2 ; P=0.0031\end{array}$} \\
\hline $\mathrm{T}^{*}$ & $65(45.1 \%)$ & $57(46.7 \%)$ & $27(26.5 \%)$ & \\
\hline $\begin{array}{l}\text { Compliance } \\
\text { with HWE }\end{array}$ & $\chi^{2}=0.1$ & $\chi^{2}=0.75$ & $\chi^{2}=1.28$ & \\
\hline
\end{tabular}

*Group 1: $O R=2.286$; 95\% CI: 1.320-3.957; $P<0.01$

*Group 2: OR=2.436; 95\% CI: 1.384-4.289; $P<0.01$

Table 3.

Distribution of alleles and genotypes of the ACE I/D polymorphism in the studied groups

\begin{tabular}{|c|c|c|c|c|}
\hline $\begin{array}{l}\text { Genotype/ } \\
\text { allele }\end{array}$ & $\begin{array}{l}\text { Group } 1 \\
(\mathrm{n}=131)\end{array}$ & $\begin{array}{l}\text { Group } 2 \\
(n=123)\end{array}$ & $\begin{array}{c}\text { Group } 3 \\
(\mathrm{n}=58)\end{array}$ & Statistics \\
\hline $\mathrm{D} / \mathrm{D}$ & $10(7.6 \%)$ & $15(12.2 \%)$ & $5(8.6 \%)$ & \multirow{3}{*}{$\begin{array}{c}\chi^{2}=2.073 \\
\mathrm{df}=4 ; P=0.7223\end{array}$} \\
\hline $\mathrm{I} / \mathrm{D}$ & $47(35.9 \%)$ & $46(37.4 \%)$ & $23(39.7 \%)$ & \\
\hline $\mathrm{I} / \mathrm{I}$ & $74(56.5 \%)$ & $62(50.4 \%)$ & $30(51.7 \%)$ & \\
\hline $\mathrm{D}$ & $67(25.6 \%)$ & $76(30.9 \%)$ & $33(28.4 \%)$ & \multirow{2}{*}{$\begin{array}{c}\chi^{2}=1.779 \\
\mathrm{df}=2 ; P=0.4109\end{array}$} \\
\hline I & $195(74.4 \%)$ & $170(69.1 \%)$ & $83(71.6 \%)$ & \\
\hline $\begin{array}{l}\text { Compliance } \\
\text { with HWE }\end{array}$ & $\chi^{2}=0.43$ & $\chi^{2}=1.9$ & $\chi^{2}=0.04$ & \\
\hline
\end{tabular}

Epidemiological studies revealed inconsistent results regarding the association of the PPARGC1A rs8192678 SNP with the metabolic syndrome pathology. Regarding T2DM, while some studies confirmed an increased risk, ${ }^{(23-27)}$ others failed to demonstrate a significant effect, or on the contrary, observed a decreased risk in the presence of the minor Ser 482 allele. ${ }^{(28-31)}$

The role of the DRD2 SNPs in the development of diabetes is not well understood. McGuire $\mathrm{V}$ et al. ${ }^{(32)}$ demonstrated that the frequency of the Taqla 'risk' allele (A1) varies according to race/ethnicity. Multiple studies have shown that the presence of at least one A1 risk (T) allele is associated with body mass index (BMI) in adults. ${ }^{(33)}$ The DRD2/ANKK1 TaqIA polymorphism could influence individual preferences for high-fat/high-sugar foods. ${ }^{(34)}$ Ramos-Lopez et al ${ }^{(34)}$ suggest that the interactions between the DRD2/ANKK1 TaqIA polymorphism and dietary factors (sugar and fats) influence triglyceride levels in diabetic patients. Barnard et al. ${ }^{(34)}$ found that the A1 (T) allele appears to be highly prevalent among individuals with type 2 diabetes. Papysheva et al. ${ }^{(35)}$ found that the DRD2/ANKK1 TaqIA (rs1800497) is involved in carbohydrate and lipid metabolism disorders in pregnant women with GDM. Potential influence of the DRD2/ANKK1 TaqIA polymorphism on GDM merits further exploration.
In conclusion, a study of the DRD2/ANKK1 TaqIA (rs1800497 SNP), PPARGC1A rs8192678 SNP, and ACE I/D revealed statistically significant increased risks for GDM in carriers of the TT genotype and T allele of the DRD2/ANKK1 TaqIA (rs1800497 SNP).

\section{Competing Interests}

The authors declare that they have no competing interests.

\section{References}

1. Radzinsky VE, Botasheva TL, Kotaysh GA. Obesity. Diabetes. Pregnancy. Versions and contraversions, clinical practices, prospects. M.: GEOTAR-Media, 2020.

2. Orazmuradov AA, Akhmatova AN, Savenkova IV, Arakelyan GA, Damirova KF, Haddad Kh., OrazmuradovaAA. Influence of Gestational Weight Gain on the Development of Complications of Gestational Diabetes Mellitus: A Literature Review. Sys Rev Pharm. 2020;11(7):462-464.

3. Orazmuradov AA, Savenkova IV, Arakelyan GA, Damirova SF, Papysheva OV, Lukanovskaya OB. Peculiar Properties of Metabolism Women with Gestational Diabetes Mellitus. Sys Rev Pharm. 2020;11(2):237-241.

4. Orazmuradov AA, Damirova SF, Savenkova IV, Arakelyan GA, Barinova EK, Haddad Kh. Prediction and Pregravid Preparation of Women with High-Risk Development of Gestational Diabetes Mellitus. Sys Rev Pharm. 2020;11(6):175-178.

5. Orazmuradov AA, Papysheva OV, Soyunov MA, Bekbaeva IV, Arakelyan GA, Haddad Kh, Lopatin AM, et al. Peculiar Properties of Pregnancy and Childbirth in Women with Gestational Diabetes Mellitus Depending on Body Weight. Sys Rev Pharm. 2020 11(11):1338-1340.

6. Aggarwal P, Agarwal N, Das N, Dalal K. Association of polymorphisms in angiotensin-converting enzyme gene with gestational diabetes mellitus in Indian women. Int J Appl Basic Med Res. 2016 Jan-Mar;6(1):31-7. doi: 10.4103/2229516X.174006.

7. Zhou JB, Yang JK, Lu JK, An YH. Angiotensin-converting enzyme gene polymorphism is associated with type 2 diabetes: a meta-analysis. Mol Biol Rep. 2010 Jan;37(1):67-73. doi: 10.1007/s11033-009-9648-6.

8. Mirfeizi M, Hasanzad M, Sattari M, Afshari M, Abbasi D, Ajoodani Z, Sheykheslam AB. Association of eNOS and ACE gene polymorphisms as a genetic risk factor in gestational diabetes in Iranian women. J Diabetes Metab Disord. 2018 Aug 6;17(2):123-127. doi: 10.1007/s40200018-0348-4. Erratum in: J Diabetes Metab Disord. 2020 Jun 25;19(2):2063.

9. Wu H, Deng X, Shi Y, Su Y, Wei J, Duan H. PGC-1 $\alpha$, glucose metabolism and type 2 diabetes mellitus. J Endocrinol. 2016 Jun;229(3):R99-R115. doi: 10.1530/JOE-16-0021.

10. Vohl MC, Houde A, Lebel S, Hould FS, Marceau P. Effects of the peroxisome proliferator-activated receptor-gamma coactivator-1 Gly482Ser variant on features of the metabolic syndrome. Mol Genet Metab. 2005 Sep-Oct;86(1-2):300-6. doi: 10.1016/j.ymgme.2005.07.002.

11. Rodgers JT, Lerin C, Gerhart-Hines Z, Puigserver P. Metabolic adaptations through the PGC-1 alpha and SIRT1 pathways. FEBS Lett. 2008 Jan 9;582(1):46-53. doi: 10.1016/j. febslet.2007.11.034. 
12. Choi YS, Hong JM, Lim S, Ko KS, Pak YK. Impaired coactivator activity of the Gly482 variant of peroxisome proliferator-activated receptor gamma coactivator-1alpha (PGC-1alpha) on mitochondrial transcription factor A (Tfam) promoter. Biochem Biophys Res Commun. 2006 Jun 9;344(3):708-12. doi: 10.1016/j.bbrc.2006.03.193.

13. Fanelli M, Filippi E, Sentinelli F, Romeo S, Fallarino M, Buzzetti R, et al. The Gly482Ser missense mutation of the peroxisome proliferator-activated receptor gamma coactivator-1 alpha (PGC-1 alpha) gene associates with reduced insulin sensitivity in normal and glucose-intolerant obese subjects. Dis Markers. 2005;21(4):175-80. doi: 10.1155/2005/576748.

14. Savitz J, Hodgkinson CA, Martin-Soelch C, Shen PH, Szczepanik J, Nugent AC, et al. DRD2/ANKK1 Taq1A polymorphism (rs1800497) has opposing effects on D2/3 receptor binding in healthy controls and patients with major depressive disorder. Int J Neuropsychopharmacol. 2013 Oct;16(9):2095-101. doi: 10.1017/S146114571300045X.

15. Noble EP, Noble RE, Ritchie T, Syndulko K, Bohlman MC, Noble LA, Zhang Y, Sparkes RS, Grandy DK. D2 dopamine receptor gene and obesity. Int J Eat Disord. 1994 Apr;15(3):205-17.

16. Stice E, Yokum S, Zald D, Dagher A. Dopamine-based reward circuitry responsivity, genetics, and overeating. CurrTop Behav Neurosci. 2011;6:81-93. doi: 10.1007/7854_2010_89. 17. Cardel MI, Lemas DJ, Lee AM, Miller DR, Hüo T, Klimentidis YC, Fernandez JR. Taq1a polymorphism (rs1800497) is associated with obesity-related outcomes and dietary intake in a multi-ethnic sample of children. Pediatr Obes. 2019 Feb;14(2):e12470. doi: 10.1111/ijpo.12470.

18. ACOG Practice Bulletin No. 190: Gestational Diabetes Mellitus. Obstet Gynecol. 2018 Feb;131(2):e49-e64. doi: 10.1097/AOG.0000000000002501.

19. Cambien F, Poirier O, Lecerf L, Evans A, Cambou JP, Arveiler D, et al. Deletion polymorphism in the gene for angiotensin-converting enzyme is a potent risk factor for myocardial infarction. Nature. 1992 Oct 15;359(6396):641-4. doi: $10.1038 / 359641 \mathrm{a} 0$.

20. Ek J, Andersen G, Urhammer SA, Gaede PH, Drivsholm $\mathrm{T}$, Borch-Johnsen K, Hansen T, Pedersen O. Mutation analysis of peroxisome proliferator-activated receptor-gamma coactivator-1 (PGC-1) and relationships of identified amino acid polymorphisms to Type II diabetes mellitus. Diabetologia. 2001 Dec;44(12):2220-6. doi: 10.1007/s001250100032.

21. Grandy DK, Zhang Y, Civelli O. PCR detection of the TaqA RFLP at the DRD2 locus. Hum Mol Genet. 1993 Dec;2(12):2197. doi: 10.1093/hmg/2.12.2197-a.

22. Rodriguez S, Gaunt TR, Day IN. Hardy-Weinberg equilibrium testing of biological ascertainment for Mendelian randomization studies. Am J Epidemiol. 2009 Feb 15;169(4):505-14. doi: 10.1093/aje/kwn359.

23. Andersen G, Hansen T, Gharani N, Fraiyling TM, Owen KR, Sampson M, Ellard S, Walker M, Hitman GA, Hattersley A, Mccarthy MI, Pedersen O.A common Gly482Ser polymorphism of PGC-1 is associated with type 2 diabetes mellitus in two European populations. Diabetes. 2002;51:A49-50.

24. Kunej T, Globocnik Petrovic M, Dovc P, Peterlin B, Petrovic D. A Gly482Ser polymorphism of the peroxisome proliferator-activated receptor-gamma coactivator-1 (PGC-1) gene is associated with type 2 diabetes in Caucasians. Folia Biol (Praha). 2004;50(5):157-8.

25. Shokouhi S, Haghani K, Borji P, Bakhtiyari S. Association between PGC-1alpha gene polymorphisms and type 2 diabetes risk: a case-control study of an Iranian population. Can J Diabetes. 2015 Feb;39(1):65-72. doi: 10.1016/j. jcjd.2014.05.003.

26. Jemaa Z, KallelA, Sleimi C, Mahjoubi I, Feki M, Ftouhi B, et al. The Gly482Ser polymorphism of the peroxisome proliferatoractivated receptor-g coactivator-1a (PGC-1a) is associated with type 2 diabetes in Tunisian population. Diabetes \& Metabolic Syndrome: Clinical Research \& Reviews. 2015;9(4):316-319. 27. Villegas R, Williams SM, Gao YT, Long J, Shi J, Cai H, et al.; AGEN-T2D Consortium, Hu F, Cai Q, Zheng W, Shu $\mathrm{XO}$. Genetic variation in the peroxisome proliferator-activated receptor (PPAR) and peroxisome proliferator-activated receptor gamma co-activator 1 (PGC1) gene families and type 2 diabetes. Ann Hum Genet. 2014 Jan;78(1):23-32. doi: 10.1111/ahg. 12044.

28. Lacquemant C, Chikri M, Boutin P, Samson C, Froguel P. No association between the G482S polymorphism of the proliferator-activated receptor-gamma coactivator-1 (PGC-1) gene and Type II diabetes in French Caucasians. Diabetologia. 2002 Apr;45(4):602-3; author reply 604. doi: 10.1007/s00125002-0783-z.

29. Stumvoll M, Fritsche A, t'Hart LM, Machann J, Thamer C, Tschritter O, et al. The Gly482Ser variant in the peroxisome proliferator-activated receptor gamma coactivator-1 is not associated with diabetes-related traits in non-diabetic German and Dutch populations. Exp Clin Endocrinol Diabetes. 2004 May;112(5):253-7. doi: 10.1055/s-2004-817972.

30. Vohl MC, Houde A, Lebel S, Hould FS, Marceau P. Effects of the peroxisome proliferator-activated receptor-gamma coactivator-1 Gly482Ser variant on features of the metabolic syndrome. Mol Genet Metab. 2005 Sep-Oct;86(1-2):300-6. doi: 10.1016/j.ymgme.2005.07.002.

31. Esterbauer $\mathrm{H}$, Oberkofler $\mathrm{H}$, Linnemayr V, Iglseder B, Hedegger M, Wolfsgruber P, Paulweber B, Fastner G, Krempler F, Patsch W. Peroxisome proliferator-activated receptor-gamma coactivator-1 gene locus: associations with obesity indices in middle-aged women. Diabetes. 2002 Apr;51(4):1281-6. doi: 10.2337/diabetes.51.4.1281.

32. McGuire V, Van Den Eeden SK, Tanner CM, Kamel F, Umbach DM, Marder K, et al. Association of DRD2 and DRD3 polymorphisms with Parkinson's disease in a multiethnic consortium. J Neurol Sci. 2011 Aug 15;307(1-2):22-9. doi: 10.1016/j.jns.2011.05.031.

33. Barnard ND, Noble EP, Ritchie T, Cohen J, Jenkins DJ, Turner-McGrievy G, Gloede L, Green AA, Ferdowsian H. D2 dopamine receptor Taq1A polymorphism, body weight, and dietary intake in type 2 diabetes. Nutrition. 2009 Jan;25(1):5865. doi: 10.1016/j.nut.2008.07.012.

34. Ramos-Lopez O, Mejia-Godoy R, Frías-Delgadillo KJ, Torres-Valadez R, Flores-García A, Sánchez-Enríquez S, et al. Interactions between DRD2/ANKK1 TaqIA Polymorphism and Dietary Factors Influence Plasma Triglyceride Concentrations in Diabetic Patients from Western Mexico: A Cross-sectional Study. Nutrients. 2019 Nov 22;11(12):2863. doi: $10.3390 /$ nu11122863.

35. Papysheva OV, Nurbekov MK, Mayatskaya TA, Kotaysh GA, Kozhevnikova EN, Shchipkova ES, Morozov SG. Influence of the PGC1 $\alpha, \mathrm{ACE}$ and DRD2 gene polymorphisms on the development and the course of gestational diabetes. Gynecology, Obstetrics and Perinatology. 2020;19(3):63-71. doi: 10.20953/1726-1678-2020-3-63-71. [Article in Russian]. 